\title{
Anatomical Basis for Optimal Use of Water for Maintenance of Three Xerophytic Plants
}

\author{
Abdullahi Alanamu ABDULRAHAMAN**, Felix Ayotunde OLADELE \\ University of Ilorin, Faculty of Science, Department of Plant Biology, 1515, Ilorin, Kwara State, \\ Nigeria; abdulrahamanaa@unilorin.edu.ng (*correspondingauthor)
}

\begin{abstract}
Three xerophytic plant species namely Agave americana Linn., Aloe vera Tourn. and Linn. and Euphorbia milii Des Moul. were propagated in a greenhouse each with 5 varying soil moisture contents i.e. $1.25 \%, 2.5 \%, 5 \%, 10 \%$, and $20 \%$ and subjected to 4 watering frequencies i.e. daily, weekly, biweekly and monthly. Euphorbia milii was the most xerophytic species having relatively lower rate of transpiration than Aloe vera and Agave americana. It was suggested that the high rate of transpiration in Aloe vera and Agave americana may be due to the large tetracytic stomata as compared to the small paracytic stomata of Euphorbia milii. It was also observed that Aloe vera was least tolerant of high soil moisture in daily watering as well as low soil moisture in monthly regime. Agave americana and Euphorbia milii were species that were more robust with capacity to cope well with low and high watering regimes than Aloe vera.
\end{abstract}

Keywords: anatomical features, conservation of water, plant leaf, transpiration rate, xerophytic plants, water stress

\section{Introduction}

Water cycle, water stress, transpiration and indeed plants with their stomatal opening and closing potentials are inseparable. Many empirical explanations have been postulated on the four. Plants are producers on whose other organisms depend for survival especially for food supply. Production of foods especially sugars is through photosynthesis which involves absorption of carbon dioxide $\left(\mathrm{CO}_{2}\right)$ through openings (i.e. stomata) in the leaves but as $\mathrm{CO}_{2}$ comes in to the leaves water vapour also escapes outward to the atmosphere (Boyer et al., 1997; Xu and Zhou, 2008). Therefore, water loss is an inevitable consequence of stomatal opening for photosynthetic carbon gain (Caird et al., 2007), and this contributes greatly to water stress in plants and consequently to poor growth and development of plants. Transpiration is at the same time known to participate actively in water cycle in the planet Earth because about $2 / 3$ of water in the water cycle passed through the plants. Because of problems of inadequate water supply and unavoidable water loss through transpiration most plants thus become water-stressed. There must always be adequate supply of water to plants in term of quantity, quality and frequency for them to perform better. With current water scarcity in the world where water availability per head is too low, there may be no room for water wastage on irrigation. Therefore there must be ways of judiciously using the available water maximally to achieve optimal yield while still conserving water. Meanwhile, water use efficiency (WUE) of a plant becomes predominant in lieu of water scarcity in the world today, and this will thus depend on water saving capacity (WSC) of plant.
Due to the fact that more water get lost through transpiration at higher rate leads to wilting and eventual death of many plants, makes some researchers contest the acclaimed benefit of transpiration. Tanner and Beevers (2001) reported that there is no possible interrelationship between transpiration and long-distance transport of mineral ions along xylem tissues of plants. This was the result of an experiment performed with Helianthus anuus. They found that convective water transport in the xylem, brought about by root pressure and resultant guttation and Munch's phloem counter flow is in itself sufficient for long-distance mineral supply and that transpiration is not required for this function. Therefore, researchers are studying ways to reduce evapotranspiration as a means of meeting the increasing demand for water in agricultural, industrial, and general use. In this situation, understanding adequate watering frequencies, amount and time, is paramount to avoiding wastage of water on irrigation by preventing irregular and indiscriminate watering.

However, there are no clear cut amount of water requirements and frequencies of watering to be used for irrigating most plants in the literatures. Terms such as constantly moist, allow to dry between watering, moderately moist, frequent watering, infrequent watering, water in a week or weeks or a month and tolerant to drought are often used. These terms can be confusing. They are not precise and can be interpreted in many ways which result in plant injury. Few plants are able to grow in constantly soggy soil. Few plants can last long in soil which has dried out completely. Between these two extremes is plenty of room for watering mistakes. 
54

Unfortunately, studies describing how stomatal features (e.g. stomatal density, stomatal index, stomatal size) of plants respond to different water stresses, relationships with gas exchange especially transpiration are few so far. The objective of this study was to determine the responses of stomatal features to different water status, and to develop the relationship of stomatal features with transpiration rate of Agave americana, Aloe vera and Euphorbia milii, based on a greenhouse experiment with a soil moisture gradient.

\section{Materials and methods}

The study materials namely Agave americana, Aloe vera and Euphorbia milii were propagated using offsets and stem cuttings, placed in plastic pots of oven-dried loamy soil, given watering regimes as shown in Tab. 1 (Walter, 1979).

The experiments were conducted in a greenhouse at University of Ilorin, Ilorin, Nigeria, for 6 weeks using 4

Tab. 1. Soil and water regimes used for raising the study materials

\begin{tabular}{ccc}
\hline Soil $(\mathrm{g})$ & Water $(\mathrm{g})$ & $\begin{array}{c}\text { \%Moisture content } \\
\text { (Water regime) }\end{array}$ \\
\hline 1600 & 400 & 20 \\
1800 & 200 & 10 \\
1900 & 100 & 5 \\
1950 & 50 & 2.5 \\
1975 & 25 & 1.25 \\
\hline
\end{tabular}

Tab. 2. Watering frequencies and regimes used for raising seedlings of the study materials

\begin{tabular}{cc}
\hline Watering intervals & Soil moisture content (\%) \\
\hline \multirow{3}{*}{ Daily } & 1.25 \\
& 2.5 \\
& 5 \\
& 10 \\
Weekly & 20 \\
\hline & 1.25 \\
& 2.5 \\
& 5 \\
& 10 \\
Biweekly & 20 \\
\hline & 1.25 \\
& 2.5 \\
& 5 \\
Monthly & 10 \\
& 20 \\
\hline & 1.25 \\
& 2.5 \\
& 5 \\
\hline & 10 \\
\hline
\end{tabular}

watering intervals as shown in Tab. 2. Number of replicates was 15 and a total of 300 pots per species were used.

After six weeks, the seedlings were taken to the laboratory for morphological and anatomical studies, leaf area measurement and determination of transpiration rate.

The leaf area $(L A)$ was determined by using the formula: $\mathrm{L} \times \mathrm{B} \times \mathrm{K}$ (Franco, 1939).

Where $\mathrm{L}=$ Length; $\mathrm{B}=$ Breadth; $\mathrm{K}=$ Franco's constant $=0.79$

Samples of leaves used were taken from different parts of the plant body i.e. upper, middle and lower parts. A sample size of 35 leaves was used for each species.

A cobalt chloride paper method was used to determine the transpiration rate of each specimen (Dutta, 2003; Obiremi and Oladele, 2001). Strips of filter paper of $2 \mathrm{~cm}$ x $6 \mathrm{~cm}$ dimension were cut and immersed in 20\% cobalt chloride solution. The strips were thoroughly dried in an oven. The property of cobalt paper is that they are deep blue when dried, but in contact with moisture they turn pink. The blue, dried strips were placed in a sealed, airtight polythene bag and weighed (W1) using mettler balance. It was transferred quickly to the plastic containers and affixed with a string to the plants. Two dried cobalt papers were placed on the leaf, one on the upper and the other one on the lower surface of a thick healthy leaf, and were covered completely with glass slides (Dutta, 2003). The time (in seconds) taken for the strips to turn pink was noted. Once turned pink, the bag was quickly untied and sealed again and weighed (W2). Weight of water transpired was determined as W2 minus W1. The surface area of leaves used was measured. Transpiration rate was expressed as $\mathrm{mol} \mathrm{m} \mathrm{sec}^{-2}$.

Leaf segment of an area of $1 \mathrm{~cm}$ square from each specimen was cut and immersed in concentrated solution of nitric acid or trioxonitrate (v) acid for maceration. The upper (adaxial) and lower (abaxial) surfaces were separated with dissecting needle and forceps, and rinsed with clean water. Using 35 fields of view at X40 objective as quadrats, the number of subsidiary cells per stoma was noted to determine the frequency of the different complex types present in each specimen. Frequency of each complex type was expressed as percentage occurrence of each stomatal complex type based on occurrences of all stomatal complex types. Terminologies used followed those of Dilcher (1974). The stomatal density was determined as the number of stomata per square millimeter (Stace, 1965).

Stomatal index $(\mathrm{SI})$ was determined as follows:

$\mathrm{SI}=\mathrm{S} / \mathrm{E}+\mathrm{S} \times 100$

Where: SI = stomatal index; $S=$ number of stomata per square millimeter; $E=$ number of ordinary epidermal cells per square millimeter.

The mean stomatal size of a species was determined as product of length and breadth of guard cells. A sample of 35 stomata was used per seedlings of a watering regime. From both upper and lower surfaces, presence or absence 
of stomata was noted to determine the leaf type whether it is epistomatic, hypostomatic or amphistomatic.

All data generated were analyzed using Analysis of Variance (ANOVA) and significant differences or means were separated with Duncan's Multiple Range Test (DMRT). A probability value of $<0.05$ was used as bench mark for significant difference between parameters.

\section{Results and discussion}

\section{Leaf emergence}

Leaf emergence was observed first in 7 days in offsets watered with $10 \mathrm{cc}$ monthly watering regime in $A$. americana while the least germination occurred in 34 days in offsets watered with $20 \mathrm{cc}$ monthly and $20 \mathrm{cc}$ weekly watering regimes of $A$. americana and $A$. vera respectively (Tab. 3). Rate of mortality of offsets and cuttings was high in monthly and biweekly watering regimes than in daily and weekly watering regimes. This corroborates the results of experiments on tomato (Dahal et al., 1996), $A r$ temisia sphaerocephala (Zheng et al., 2005a), Hedysarum fruticosum (Zheng et al., 2005b), Anthemis cotula (Rashid et al., 2007) and Omphalea oleifera (Sanchez-Coronado et al., 2007) where water stress resulted in total reduction of seed germination.

Tab. 3. Leaf emergence/germination period in three xerophytic species raised with percentage moisture contents

\begin{tabular}{|c|c|c|c|}
\hline $\begin{array}{l}\text { Watering } \\
\text { regime }(\%)\end{array}$ & $\begin{array}{c}\text { Agave } \\
\text { americana }\end{array}$ & Aloe vera & $\begin{array}{c}\text { Euphorbia } \\
\text { milii }\end{array}$ \\
\hline \multicolumn{4}{|c|}{ Daily } \\
\hline 1.25 & $21 b$ & $13 \mathrm{~d}$ & $20 \mathrm{~b}$ \\
\hline 2.5 & $11 d$ & $9 \mathrm{e}$ & $15 d$ \\
\hline 5 & $24 b$ & $8 \mathrm{e}$ & -- \\
\hline 10 & $15 \mathrm{c}$ & -- & $13 e$ \\
\hline 20 & $12 \mathrm{~d}$ & -- & $15 \mathrm{~d}$ \\
\hline \multicolumn{4}{|c|}{ Weekly } \\
\hline 1.25 & - & - & $11 \mathrm{f}$ \\
\hline 2.5 & -- & -- & $17 \mathrm{c}$ \\
\hline 5 & -- & -- & $17 \mathrm{c}$ \\
\hline 10 & $16 \mathrm{c}$ & $22 b$ & $18 \mathrm{c}$ \\
\hline 20 & $24 \mathrm{~b}$ & $34 \mathrm{a}$ & $13 \mathrm{e}$ \\
\hline \multicolumn{4}{|c|}{ Biweekly } \\
\hline 1.25 & - & - & - \\
\hline 2.5 & - & -- & $20 \mathrm{~b}$ \\
\hline 5 & -- & -- & -- \\
\hline 10 & $14 \mathrm{~cd}$ & $9 \mathrm{e}$ & $20 \mathrm{~b}$ \\
\hline 20 & $13 \mathrm{~d}$ & $17 \mathrm{c}$ & -- \\
\hline \multicolumn{4}{|c|}{ Monthly } \\
\hline 1.25 & -- & - & - \\
\hline 2.5 & -- & -- & $26 a$ \\
\hline 5 & -- & -- & -- \\
\hline 10 & $7 \mathrm{e}$ & -- & $11 f$ \\
\hline 20 & $34 \mathrm{a}$ & -- & $13 \mathrm{e}$ \\
\hline
\end{tabular}

Means with same letters along the rows are not significantly different at $p<0.05$

\section{Stomatal complex types}

Agave americana and Aloe vera consistently showed tetracytic stomata (Fig. 1 and 2) while Euphorbia milii had paracytic stomata (Fig. 3) under all watering regimes. Variations were, however, observed in the values of stomatal size, stomatal density and stomatal index (Tab. 4 and 6). In Agave americana, the range of variation for stomatal density was 1.55-4.38, that for stomatal index was 1.38-5.39 and that for stomatal size was 91.95-628.84 (Tab. 4). In Aloe vera, the range of variation in stomatal density was 0.38 2.50 , that in stomatal index was $0.91-4.46$ and that for stomatal size 144.87-534.39 (Tab. 5). In Euphorbia milii, the range of variation in stomatal density was 9.25-21.00; that of stomatal index was 5.10-10.41 while that of stomatal size was 48.13-86.74 (Tab. 4). Stomatal features such as its density had been correlated positively with water use efficiency (WUE) of plants (Klooster, 2004; Shan, 1991; Shi, 1999; Wang et al., 2007; Xu and Zhou, 2008). Similarly, several reports have shown that the stomatal density and its index increase with water stress (Yang and Wang, 2001; Zhang et al., 2006), but the number of stomata per leaf decrease (Quarrie and Jones, 1977). AbdulRahaman and Oladele (2003), Oyeleke et al. (2004) had earlier observed similar pattern of stomatal density, index and size on the
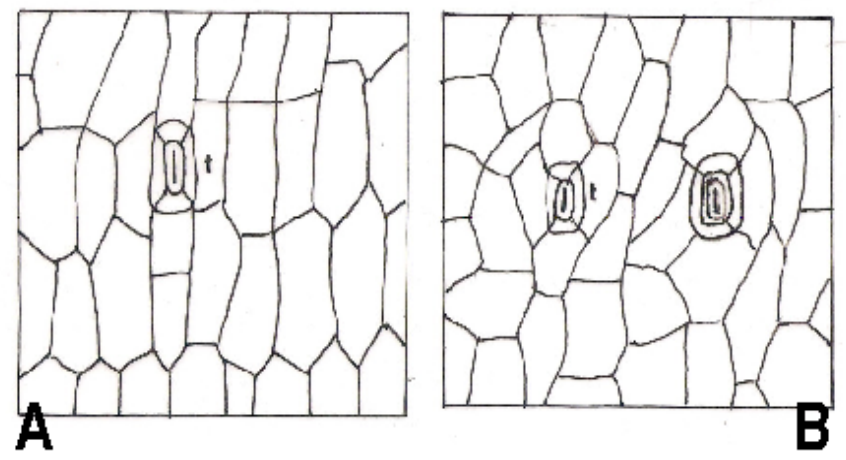

Fig. 1. Surface view of leaf epidermis, abaxial (A) and adaxial (B) of Agave americana propagated with $1.25 \mathrm{cc}$ daily watering regime showing tetracytic $(\mathrm{t})$ stomata $\mathrm{x} 1200$
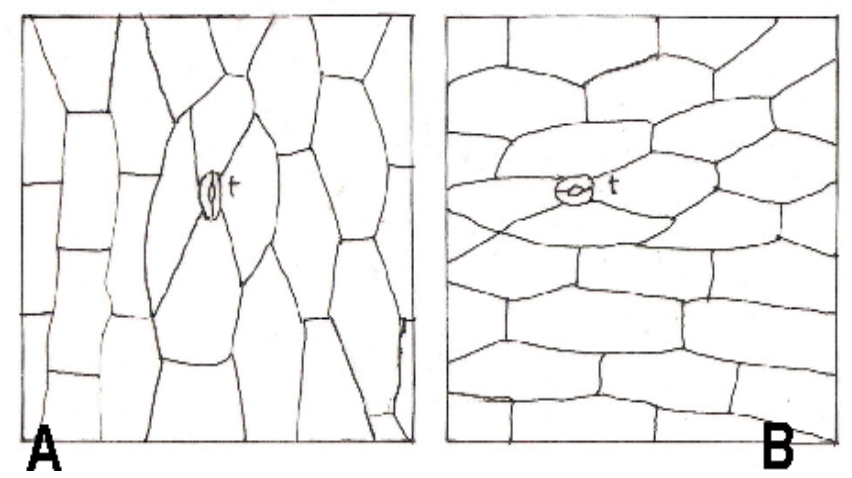

Fig. 2. Surface view of leaf epidermis, abaxial (A) and adaxial (B) of Aloe vera propagated with $2.5 \mathrm{cc}$ daily watering regime showing tetracytic $(\mathfrak{t})$ stomata $\times 1200$ 
56
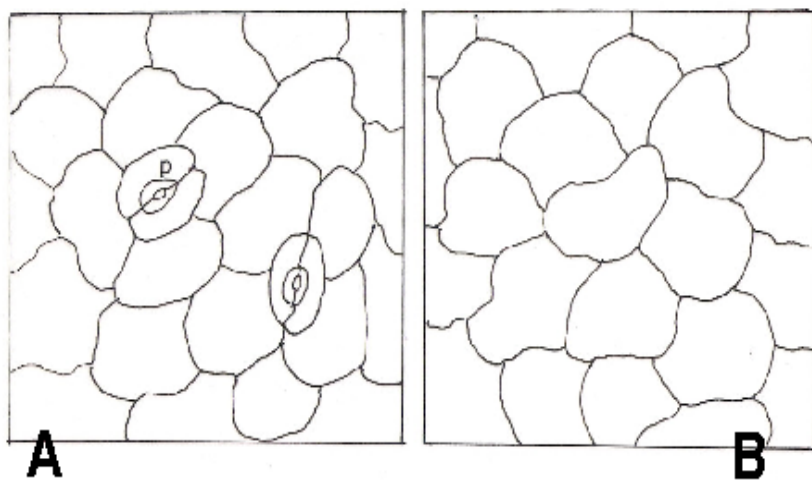

Fig. 3. Surface view of leaf epidermis, abaxial (A) and adaxial (B) of Euphorbia milii Propagated with $1.25 \mathrm{cc}$ daily watering regime showing paracytic (p) stomata $\times 1600$

Tab. 4. Stomatal anatomy of Agave americana raised with different percentage moisture contents

\begin{tabular}{|c|c|c|c|c|}
\hline $\begin{array}{c}\text { Watering } \\
\text { regimes }(\%)\end{array}$ & $\begin{array}{c}\text { Leaf } \\
\text { surface }\end{array}$ & $\begin{array}{c}\text { Stomatal } \\
\text { density }\left(\mathrm{mm}^{-2}\right)\end{array}$ & $\begin{array}{l}\text { Stomatal } \\
\text { index }(\%)\end{array}$ & $\begin{array}{l}\text { Stomatal } \\
\text { size (um) }\end{array}$ \\
\hline \multicolumn{5}{|c|}{ Daily } \\
\hline \multirow{2}{*}{1.25} & Abaxial & $2.91 \mathrm{c}$ & $3.54 \mathrm{e}$ & $499.50 \mathrm{~b}$ \\
\hline & Adaxial & $4.13 \mathrm{a}$ & $5.15 b$ & $360.56 c$ \\
\hline \multirow{2}{*}{2.5} & Abaxial & $2.05 \mathrm{~cd}$ & $2.85 \mathrm{ef}$ & $557.62 \mathrm{a}$ \\
\hline & Adaxial & $3.85 b$ & $5.35 b$ & $331.94 \mathrm{c}$ \\
\hline \multirow{2}{*}{5} & Abaxial & $2.45 c$ & $4.47 \mathrm{~d}$ & $475.34 \mathrm{~b}$ \\
\hline & Adaxial & $2.50 \mathrm{c}$ & $3.56 \mathrm{e}$ & $222.33 d$ \\
\hline \multirow{2}{*}{10} & Abaxial & $1.55 \mathrm{~d}$ & 1.38 & $381.77 \mathrm{c}$ \\
\hline & Adaxial & $2.00 \mathrm{~cd}$ & $2.33 \mathrm{ef}$ & $360.93 c$ \\
\hline \multirow{2}{*}{20} & Abaxial & $3.13 b c$ & $3.92 \mathrm{e}$ & $504.32 \mathrm{ab}$ \\
\hline & Adaxial & $4.38 \mathrm{a}$ & $6.12 \mathrm{a}$ & $336.16 c$ \\
\hline \multicolumn{5}{|c|}{ Weekly } \\
\hline \multirow{2}{*}{10} & Abaxial & $1.57 \mathrm{~d}$ & $2.34 \mathrm{ef}$ & $338.30 \mathrm{c}$ \\
\hline & Adaxial & $1.73 \mathrm{~d}$ & $2.21 \mathrm{ef}$ & $275.50 \mathrm{~d}$ \\
\hline \multirow{2}{*}{20} & Abaxial & 2.75 & $5.39 \mathrm{~b}$ & $440.59 \mathrm{bc}$ \\
\hline & Adaxial & $2.11 \mathrm{~cd}$ & $4.94 \mathrm{~d}$ & $309.17 \mathrm{c}$ \\
\hline \multicolumn{5}{|c|}{ Biweekly } \\
\hline \multirow{2}{*}{10} & Abaxial & $3.71 \mathrm{~b}$ & $4.07 \mathrm{~d}$ & $252.86 \mathrm{~d}$ \\
\hline & Adaxial & $4.38 \mathrm{a}$ & $5.26 \mathrm{~b}$ & $91.95 \mathrm{e}$ \\
\hline \multirow{2}{*}{20} & Abaxial & $2.63 c$ & $3.73 \mathrm{e}$ & $628.84 a$ \\
\hline & Adaxial & $3.88 \mathrm{~b}$ & $5.11 \mathrm{~b}$ & $521.25 \mathrm{a}$ \\
\hline \multicolumn{5}{|c|}{ Monthly } \\
\hline \multirow{2}{*}{10} & Abaxial & $2.67 \mathrm{c}$ & $4.10 \mathrm{~d}$ & $99.56 \mathrm{e}$ \\
\hline & Adaxial & $2.00 \mathrm{~cd}$ & $3.01 \mathrm{e}$ & $93.75 \mathrm{e}$ \\
\hline \multirow{2}{*}{20} & Abaxial & $2.00 \mathrm{~cd}$ & $2.58 \mathrm{ef}$ & $446.28 b$ \\
\hline & Adaxial & $3.86 \mathrm{~b}$ & $4.80 \mathrm{~d}$ & $341.19 \mathrm{c}$ \\
\hline
\end{tabular}

Means with same letters along the columns are not significantly different at $p<0.05$

abaxial and adaxial leaf surfaces of some vegetable species and some afforestation species respectively.

\section{Transpiration rate}

In daily watering regime, Aloe vera had higher rate of transpiration than Agave americana and Euphorbia milii at $1.25-5 \%$ soil moisture (Tab. 7). But the species was less tolerant of high soil moisture in daily watering and low soil
Tab. 5. Stomatal anatomy of Aloe vera raised with different percentage moisture contents

\begin{tabular}{ccccc}
\hline $\begin{array}{c}\text { Watering } \\
\text { regimes }(\%)\end{array}$ & $\begin{array}{c}\text { Leaf } \\
\text { surface }\end{array}$ & $\begin{array}{c}\text { Stomatal } \\
\text { density }\left(\mathrm{mm}^{-2}\right)\end{array}$ & $\begin{array}{c}\text { Stomatal } \\
\text { index }(\%)\end{array}$ & $\begin{array}{c}\text { Stomatal } \\
\text { size }(\mu \mathrm{m})\end{array}$ \\
\hline \multirow{5}{*}{1.25} & Daily & & \\
& Abaxial & $0.38 \mathrm{c}$ & $0.91 \mathrm{~d}$ & $195.64 \mathrm{~d}$ \\
& Adaxial & $0.50 \mathrm{c}$ & $1.54 \mathrm{c}$ & $253.12 \mathrm{c}$ \\
& Abaxial & $0.60 \mathrm{c}$ & $1.55 \mathrm{c}$ & $236.90 \mathrm{c}$ \\
& Adaxial & $1.00 \mathrm{~b}$ & $2.66 \mathrm{~b}$ & $287.83 \mathrm{c}$ \\
\multirow{2}{*}{5} & Abaxial & $2.50 \mathrm{a}$ & $3.65 \mathrm{a}$ & $261.67 \mathrm{c}$ \\
& Adaxial & $0.75 \mathrm{c}$ & $1.86 \mathrm{c}$ & $249.75 \mathrm{c}$ \\
\hline \multirow{5}{*}{10} & Weekly & & \\
\hline \multirow{2}{*}{20} & Abaxial & $2.63 \mathrm{a}$ & $4.46 \mathrm{a}$ & $534.39 \mathrm{a}$ \\
& Adaxial & $2.13 \mathrm{a}$ & $3.36 \mathrm{a}$ & $334.95 \mathrm{~b}$ \\
& Abaxial & $0.80 \mathrm{c}$ & $1.82 \mathrm{c}$ & $215.00 \mathrm{c}$ \\
& Adaxial & $0.70 \mathrm{c}$ & $1.51 \mathrm{c}$ & $284.66 \mathrm{c}$ \\
\hline \multirow{5}{*}{10} & Biweekly & \\
\hline \multirow{2}{*}{20} & Abaxial & $0.63 \mathrm{c}$ & $1.36 \mathrm{c}$ & $144.87 \mathrm{~d}$ \\
& Adaxial & $0.38 \mathrm{c}$ & $1.04 \mathrm{c}$ & $195.58 \mathrm{~d}$ \\
& Abaxial & $0.80 \mathrm{c}$ & $1.82 \mathrm{c}$ & $215.00 \mathrm{c}$ \\
& Adaxial & $0.70 \mathrm{c}$ & $1.51 \mathrm{c}$ & $284.66 \mathrm{c}$ \\
\hline
\end{tabular}

Means with same letters along the columns are not significantly different at $p<0.05$

Tab. 6. Stomatal anatomy of Euphorbia milii raised with different percentage moisture contents

\begin{tabular}{|c|c|c|c|c|}
\hline $\begin{array}{l}\text { Watering } \\
\text { regimes }(\%)\end{array}$ & $\begin{array}{c}\text { Leaf } \\
\text { surface }\end{array}$ & $\begin{array}{c}\text { Stomatal } \\
\text { density }\left(\mathrm{mm}^{-2}\right)\end{array}$ & $\begin{array}{r}\text { Stomatal } \\
\text { index }(\%)\end{array}$ & $\begin{array}{l}\text { Stomatal } \\
\text { size }(\mu \mathrm{m})\end{array}$ \\
\hline \multicolumn{5}{|c|}{ Daily } \\
\hline \multirow{2}{*}{1.25} & Abaxial & $10.33 \mathrm{e}$ & $6.55 c$ & $65.33 c$ \\
\hline & Adaxial & -- & - & -- \\
\hline \multirow{2}{*}{2.5} & Abaxial & $15.00 \mathrm{~b}$ & $9.12 \mathrm{ab}$ & $86.74 a$ \\
\hline & Adaxial & -- & -- & -- \\
\hline \multirow{2}{*}{10} & Abaxial & $10.67 \mathrm{e}$ & $4.82 \mathrm{~d}$ & $85.75 a$ \\
\hline & Adaxial & -- & -- & - \\
\hline \multirow[t]{2}{*}{20} & Abaxial & $13.75 b c$ & $8.74 b$ & $80.50 \mathrm{a}$ \\
\hline & Adaxial & -- & -- & -- \\
\hline \multicolumn{5}{|c|}{ Weekly } \\
\hline \multirow{2}{*}{2.5} & Abaxial & $12.33 \mathrm{~d}$ & $6.03 c$ & $85.68 \mathrm{a}$ \\
\hline & Adaxial & -- & -- & -- \\
\hline \multirow{2}{*}{5} & Abaxial & $21.00 \mathrm{a}$ & $10.41 \mathrm{a}$ & $80.29 a$ \\
\hline & Adaxial & -- & -- & -- \\
\hline \multirow{2}{*}{20} & Abaxial & $13.22 \mathrm{~cd}$ & $5.95 \mathrm{c}$ & $81.04 a$ \\
\hline & Adaxial & - & -- & -- \\
\hline \multicolumn{5}{|c|}{ Biweekly } \\
\hline \multirow[t]{2}{*}{2.5} & Abaxial & $10.50 \mathrm{e}$ & $5.10 \mathrm{~d}$ & $76.51 \mathrm{~b}$ \\
\hline & Adaxial & -- & -- & -- \\
\hline \multirow{2}{*}{10} & Abaxial & \multirow{2}{*}{$9.25 \mathrm{e}$} & $5.47 \mathrm{~cd}$ & $48.13 d$ \\
\hline & Adaxial & & -- & -- \\
\hline \multicolumn{5}{|c|}{ Monthly } \\
\hline \multirow{2}{*}{2.5} & Abaxial & $10.50 \mathrm{e}$ & $5.10 \mathrm{~d}$ & $76.50 \mathrm{~b}$ \\
\hline & Adaxial & -- & -- & -- \\
\hline \multirow{2}{*}{20} & Abaxial & $12.00 \mathrm{~d}$ & $6.12 c$ & $73.47 \mathrm{~b}$ \\
\hline & Adaxial & -- & -- & -. \\
\hline
\end{tabular}

Means with same letters along the columns are not significantly different at $p<0.05$ 
Tab. 7. Transpiration rate of some ornamental plant species propagated with different percentage moisture contents

\begin{tabular}{|c|c|c|c|c|c|c|}
\hline \multicolumn{7}{|c|}{ Transpiration rate $\left(\mathrm{mol} / \mathrm{m}^{2} / \mathrm{sec}^{-1}\right)$} \\
\hline \multirow{2}{*}{$\begin{array}{l}\text { Watering } \\
\text { regimes }(\%)\end{array}$} & \multicolumn{2}{|c|}{ Agave americana } & \multicolumn{2}{|c|}{ Aloe vera } & \multicolumn{2}{|c|}{ Euphorbia milii } \\
\hline & Abaxial & Abaxial & Abaxial & Abaxial & Abaxial & Abaxial \\
\hline \multicolumn{7}{|c|}{ Daily } \\
\hline 1.25 & $2.91 \times 10^{-5} \mathrm{a}$ & $3.01 \times 10^{-5} \mathrm{a}$ & $8.66 \times 10^{-5} \mathrm{a}$ & $1.13 \times 10^{-4} \mathrm{a}$ & $2.23 \times 10^{-3} \mathrm{c}$ & - \\
\hline 2.5 & $1.68 \times 10^{-5} \mathrm{a}$ & $1.70 \times 10^{-5} \mathrm{a}$ & $8.64 \times 10^{-5} \mathrm{a}$ & $1.48 \times 10^{-4} \mathrm{~b}$ & $8.38 \times 10^{-4} \mathrm{~b}$ & -- \\
\hline 5 & $3.46 \times 10^{-5} \mathrm{a}$ & $3.23 \times 10^{-5} \mathrm{a}$ & $2.22 \times 10^{-4} b$ & $1.49 \times 10^{-4} \mathrm{~b}$ & -- & -- \\
\hline 10 & $4.93 \times 10^{-5} \mathrm{a}$ & $5.05 \times 10^{-5} \mathrm{a}$ & -- & -- & $2.56 \times 10^{-3} \mathrm{c}$ & -- \\
\hline 20 & $1.05 \times 10^{-5} \mathrm{a}$ & $1.22 \times 10^{-5} \mathrm{a}$ & -- & -- & $2.03 \times 10^{-3} \mathrm{c}$ & \\
\hline \multicolumn{7}{|c|}{ Weekly } \\
\hline 2.5 & $2.82 \times 10^{-5} \mathrm{a}$ & $3.00 \times 10^{-5} \mathrm{a}$ & -- & -- & $2.23 \times 10^{-4} \mathrm{~b}$ & -- \\
\hline 5 & $1.28 \times 10^{-5} \mathrm{a}$ & $1.32 \times 10^{-5} \mathrm{a}$ & -- & -- & $8.19 \times 10^{-4} \mathrm{~b}$ & -- \\
\hline 10 & $4.21 \times 10^{-5} \mathrm{a}$ & $4.44 \times 10^{-5} \mathrm{a}$ & $1.47 \times 10^{-4} \mathrm{~b}$ & $1.11 \times 10^{-4} \mathrm{~b}$ & -- & -- \\
\hline 20 & $7.67 \times 10^{-5} \mathrm{a}$ & $1.14 \times 10^{-4} \mathrm{~b}$ & $8.67 \times 10^{-5} \mathrm{a}$ & $6.17 \times 10^{-5} \mathrm{a}$ & $1.78 \times 10^{-4} \mathrm{~b}$ & -- \\
\hline \multicolumn{7}{|c|}{ Biweekly } \\
\hline 2.5 & -- & -- & - & -- & $7.93 \times 10^{-4} \mathrm{~b}$ & \\
\hline 10 & $3.50 \times 10^{-5} \mathrm{a}$ & $3.65 \times 10^{-5} \mathrm{a}$ & $1.93 \times 10^{-4} \mathrm{~b}$ & $2.74 \times 10^{-4} \mathrm{~b}$ & $3.61 \times 10^{-4} \mathrm{~b}$ & -- \\
\hline 20 & $3.55 \times 10^{-5} \mathrm{a}$ & $2.30 \times 10^{-5} \mathrm{a}$ & $3.39 \times 10^{-4} \mathrm{~b}$ & $.70 \times 10^{-4} \mathrm{~b}$ & -- & -- \\
\hline \multicolumn{7}{|c|}{ Monthly } \\
\hline 2.5 & -- & -- & - & -- & $4.40 \times 10^{-3} \mathrm{c}$ & -- \\
\hline 10 & $6.61 \times 10^{-5} \mathrm{a}$ & $6.44 \times 10^{-5} \mathrm{a}$ & -- & -- & -- & -- \\
\hline 20 & $2.42 \times 10^{-5} \mathrm{a}$ & $2.59 \times 10^{-5} \mathrm{a}$ & -- & -- & $2.70 \times 10^{-3} \mathrm{c}$ & -- \\
\hline
\end{tabular}

Means with same letters along the rows are not significantly different at $p<0.05$

moisture in monthly watering regime (Tab. 7). The data on monthly watering regime suggested that Euphorbia milii was the most xeromorphic species followed by Agave americana and Aloe vera even though the latter species transpired less in weekly and biweekly watering regimes at 10\%-20\% soil moisture (Tab. 7). Hence Euphorbia milii requires less frequent watering than the other two species. Agave americana was the most robust in coping with all the watering regimes while Aloe vera was the least robust in this regard. The higher transpiration rate in Agave americana may be related to the tetracytic stomata and high stomatal size. While the low transpiration rate in Euphorbia milii and Aloe vera may be related to paracytic stomata and smaller size of stomata. There are therefore, significant differences at $p<0.05$ in the rate of transpiration across the soil moisture contents among the three species. Earlier work of Carr and Carr (1990) revealed that large number of subsidiary cells per stoma may be responsible for a more precise and rapid regulation of stomatal opening. This claim was confirmed by Obiremi and Oladele (2001), AbdulRahaman and Oladele (2003), Oyeleke et al. (2004) and Saadu et al. (2009) in stomatal complex types of some species of Citrus, vegetables, afforestation tree and tuber species where those stomata with large number of subsidiary cells transpired faster than those with small subsidiary cells. Meanwhile, the variation in rates of transpiration among the watering frequencies is explained by Awad and Castro (1992) that when the water supply is reduced, the stomatal guard cells lose solutes, increasing their water potential, and increasing their abscisic acid (ABA) level thus, causing reduction in their pressure potential and subsequently stomatal closure.

\section{References}

AbdulRahaman AA, Oladele FA (2003). Stomatal complex types, size, density and index in some vegetable species in Nigeria. NigJ Bot 16:144-150.

Awad M, Castro PRC (1992). Introducao a fisiologia vegetal. Nobel, Sao Paulo.

Boyer JS, Wong SC, Farquhar CD (1997). $\mathrm{CO}_{2}$ and water vapor exchange across leaf cuticle (epidermis) at various water potentials. Plant Physiol 114:185-191.

Caird MA, Richards JH, Donovan LA (2007). Nighttime stomatal conductance and transpiration in $\mathrm{C} 3$ and $\mathrm{C} 4$ plants. Plant Physiol 143(1):4-10.

Carr SG, Carr DJ (1990). Cuticular features of the central Australian bloodwoods Eucalyptus section Corymbosae (Myrtaceae). Bot J Linn Soc 102:123-156.

Dahal P, Kim NS, Bradford KJ (1996). Respiration and germination rates of tomato seeds at suboptimal temperatures and reduced water potentials. J Experim Bot 47(7):941947.

Dilcher DL (1974). Approaches to the identification of angiosperm leaf remains. Bot Rev 40:1-157.

Dutta AC (2003). Botany for Degree Students, Revised $6^{\text {th }}$ Edition. Oxford University Press, New Delhi, 240 p.

Franco C (1939). Relation between chromosome number and 
58 stomata in Coffea. Bot Gazet 100:817-818.

Klooster B, Palmer-Young E (2004). Water stress marginally increase stomatal density in E. canadensis, but not in $A$. geradii. Tillers 5:35-40.

Obiremi EO, Oladele FA (2001). Water-conserving stomatal systems in selected Citrus species. South Afr J Bot 67:258260.

Oyeleke MO, AbdulRahaman AA, Oladele FA (2004). Stomatal anatomy and transpiration rate in some afforestation tree species. Nig Soc Experiment Biol J 4(2):83-90.

Quarrie SA, Jones HG (1977). Effects of abscisic acid and water stress on development and morphology of wheat. J Experim Bot 28(1):192-203.

Rashid I, Rashi Z, Allaie RR, Wafai BA (2007). Germinationof ecology of invasive alien Anthemis cotula helps it synchronise its successful recruitment with favourable habitat conditions. Ann Appl Biol 150(3):361-369.

Saadu RO, AbdulRahaman AA, Oladele FA (2009). Stomatal complex types and humidification potential of some root tuber species. Afr J Plant Sci 3(5):107-112.

Sanchez-Coronado ME, Coates R, Castro-Colina L, Gamboa de Buen A, Paez-Valencia J, Barradas VL, Huante P, Orozco-Segovia A (2007). Improving seed germination and seedling growth of Omphalea oleifera (Euphorbiaceae) for restoration projects in tropical rain forests. For Ecol Manage 243(1):144-155.

Shan L (1991). Physiological and ecological base of water saving agriculture. J Appl Ecol 1:70-78.

Shi YC (1999). Ways of exploitation: biological water saving. Sci Technol Rev 10:3-5.
Stace CA (1965). Cuticular studies as an aid to plant taxonomy. Bull Brit Mus (Nat His) Bot 4:1-78.

Tanner W, Beevers H (2001). Transpiration, a prerequisite for long-distance transport of minerals in plants? PNAS, 98(16):9443-9447.

Walter H (1979). Vegetation of the Earth and Ecological Systems of the Geo-biosphere. $2^{\text {nd }}$ Edition. Springer Verlag, New York, 18-21 p.

Wang Y, Cheng X, Xiang C-B (2007). Stomatal density and biowater saving. J Integrat Plant Biol 49(10):1435-1444.

Xu ZZ, Zhou GS (2008). Responses of leaf stomatal density to water status and its relationship with photosynthesis in a grass. J Experim Bot 59(2):3317-3325.

Yang HM, Wang GX (2001). Leaf stomatal densities and distribution in Triticum aestivum under drought and $\mathrm{CO}_{2}$ enrichment. Acta Phytoecol Sinica 25:312-316.

Zhang YP, Wang ZM, Wu YC, Zhang X (2006). Stomatal characteristics of different green organs in wheat under different irrigation regimes. Acta Agron Sinica 32:70-75.

Zheng Y, Xie Z, Gao Y, Jiang L, Xing X, Shimisu H, Rimmingto GM (2005a). Effects of light, temperature and water stress on germination of Arthemisia shaerocephala. Ann Appl Biol 146(3):327-335.

Zheng Y, Xie Z, Gao Y, Yu Y, Shimizu H (2005b). Influence of light, temperature and water stress on germination of Hedysarum fruticosum. South Afr J Bot 71(2):167-172. 